\title{
Retrospective cost-utility and budget impact assessments of Hypericum perforatum in contrast with Fluoxetine treatment for depression in Karachi, Pakistan
}

\author{
Syed Muzzammil Ahmad ${ }^{\odot 1, *}$, Darakhshan Masroor $^{1}$, Iqbal Azhar ${ }^{1}$, Nadia Ahmed ${ }^{2}$
}

${ }^{1}$ Department of Pharmacognosy, Faculty of Pharmacy and Pharmaceutical Sciences, University of Karachi, Karachi, Pakistan, ${ }^{2}$ Department of Pharmaceutics, Faculty of Pharmacy and Pharmaceutical Sciences, University of Karachi, Karachi, Pakistan

\begin{abstract}
In this study we have compared two different types of therapies i.e. herbal and allopathic system of therapies for Depression and studied them from the social perspectives. The Hypericum perforatum is compared with Fluoxetine [HCL] in terms of cost-utility and financial savings thereby evaluating its influence on annual expenditure of depressive patients that were randomly selected from 178 union councils of the city of Karachi, Pakistan. For both system of therapies a total of 356 patients were selected by stratified random sampling. Taking frequency of depression as ' 1 ' annually with discount rate at $3 \%$ for calculating the burden-of-illness in terms of disability-adjusted-life-years. The cost-utility and the budget-impact assessments were carried out to assess incremental-cost-effectiveness-ratio, and the budget-impact-per-onset as well as budget-impact-per-year values. In comparison with the Fluoxetine therapy, the Hypericum perforatum was found to relieve symptoms in $21.47 \%$ less cost; owing $29.23 \%$ less disability-adjusted-life-years and $21.45 \%$ less budget-impact-per-onset as well as budget-impact-peryear. The annual mean incremental-cost-effectiveness-ratio was found to be at $36.95 \pm 270.74$ (less than GDP per capita threshold of Rs. 38,173.02). Hypericum perforatum provide the optimal utility with less impact on budget of a patient in comparison with the treatment of symptoms of depression with Fluoxetine.
\end{abstract}

Keywords: Hypericum perforatum. Fluoxetine. Burden of illness. Disability-Adjusted-Life-Years. Incremental-Cost-Effectiveness-Ratio.

\section{INTRODUCTION}

Depression has been identified as one of the major illnesses, which can curtail the quality of life along with the potential to aggravate hysteria in the day-to-day life. This could lead to suicide attempts that is prevailing these days; therefore, is becoming one of the apprehension of mortality in depression (Supartini, Oishi, Yagi, 2017). According to WHO depression is a psychological disorder that originates from various unspecified reasons. With a prevalence of $28.2 \%$ in young population (Oyekcin, Sahim, Aldemir, 2017) and with an annual rise to $113 \%$, this psychological condition has been affecting $4.7 \%$ of today's world population (Xu et al., 2017; Wu et al., 2017). Depression is generally characterized as the cerebral impairment categorized by

\footnotetext{
*Correspondence: S. M. Ahmad. Department of Pharmacognosy, Faculty of Pharmacy and Pharmaceutical Sciences, University of Karachi, 75270, Karachi. Phone: +92-333-2593824 / +92-322-9383863. E-mail: syed.muzzammil.ahmad@gmail.com
}

the absence of a positive demeanor. This represents a clear loss of the presence of enthusiasm and charisma for personal belongings, daily life activities as well as social participation and person becomes introvert. Depression is strongly associated with indications that represents susceptibility to mourning, peevishness and impatience, frequent withdrawals, and aggravation of a very unusual feelings (Wu et al., 2017), particularly the presence of feelings of inferiority and a state of mind for guiltiness (Zhang et al., 2016; Supartini, Oishi, Yagi, 2017). There is loss of libido and the prostration along with the diminished body movements and noticeable nervousness is more recurrent than general anxiety in depression. During the phase of depression, insomnia as well as anorexia has been seen, with very few exceptions. There are also signs of lack of self-confidence, worthlessness, emotional state of powerlessness, and merited sentence in the form of delusion or hallucinations and efforts for harming oneself or any kind of suicide (Supartini, Oishi, Yagi, 2017). The incident of suicide linked to depression 
includes a form of suicide, 'hara-kiri', however, it is not the only type of suicide that has been reported in depression (Cheung, Merry, Sundram, 2018). Even some studies suggest that the trivial activities like suicide are not in particularly linked with depression (Cheung, Merry, Sundram, 2018).

Numerous plants have been reported to have such phytochemicals that exhibit therapeutic significance as an antidepressant (Saki, Bahmani, Rafieian-Kopaei, 2014). Among them, one of the most important plants is Hypericum perforatum (Bukhari, Dar, 2013; Chrea et al., 2014; Husain et al., 2011; Russo et al., 2014; Saki, Bahmani, Rafieian-Kopaei, 2014; Sarris, 2013; Solomon, Adams, Graves, 2013; Tian et al., 2014). Under various brand names, the herbal medicine Hypericum perforatum and an allopathic medicine Fluoxetine [HCl] $20 \mathrm{mg}$ (Floxac ${ }^{\circledR} 20 \mathrm{mg}$ Tablets) - a product by The Schazoo Laboratories (Pakistan), are utilized by patients across the globe (Wong, Perry, Bymaster, 2005). Although, there is evidence of several published pharmacoeconomics studies for allopathic medicines throughout the research world, yet there is lack of such research studies on herbal medicines (Huebner et al., 2017) especially in the selected region of the city of Karachi, Pakistan.

Previously, various studies were conducted for determining epidemiology of depression and the pharmacoeconomic benefits associated with the involved therapies. For example, with respect to prevalence of depression in citizens of the United States of America, each one in twelve citizens was found affected by it (Adkins et al., 2012). As stated by the World Health Organization, at the end of the year 2020, the depression would be the next to major causes of Disability Adjusted Life Years (DALYs) expected to be misplaced globally (Al-Qadhi et al., 2014).

In Pakistan, from the year 1957 until 2016, due to the changes in consumer price index, the dynamics of the inflation rate averaged at $7.86 \%$ (Pakistan Inflation Rate, 2017). The requirement for national savings is now on the top priority list for Pakistan due to the inflation. Therefore, with respect to the treatment of depression, there was a need to assess two dissimilar therapies from the social perspective. For this, the estimation of cost per DALY and analysis of budget impact of therapies was due for the treatment of depression, i.e. the Hypericum perforatum (St. John's Wort) with Fluoxetine [HCL] (Floxac ${ }^{\circledR} 20 \mathrm{mg}$ Tablets) in terms of the cost utility, the financial savings and reducing the load of depression with the minimum influence on annual budget of a patient in population of the 178 union councils of the city of Karachi, Pakistan.

\section{MATERIAL AND METHODS}

The herb 'Hypericum perforatum' was utilized as a sample while the allopathic medicine Fluoxetine [HCL] $20 \mathrm{mg}$ (Floxac ${ }^{\circledR} 20 \mathrm{mg}$ Tablets) was selected as a control in the study. The 'Hypericum perforatum' was used as an oral infusion, i.e. in 1 cup; $200 \mathrm{mg}$ of 'Hypericum perforatum' once a day.

\section{Approval of study by ethical review committee}

The study was started after an approval of the research project from Ethical Review Committee, Faculty of Pharmacy and Pharmaceutical Sciences, University of Karachi (Project Approval Protocol, dated: September 18, 2012, ref. no. 0671/Pharm./10(28)), for data collection of depressed patients. This data collection was confined to the physiological, medical or clinical information, and was constrained for collection of any human biological materials. The methodology of the study was developed in the light of the good research practices of Pharmacoeconomics as provided by the International Society of Pharmacoeconomics and Outcome Research (ISPOR) (Eddy et al., 2012). The methods were validated (Eddy et al., 2012) and replicated for the other two studies of the same series of research, i.e. for common cold and trauma in the 178 union councils of the city of Karachi.

\section{Setting and sample}

The required sample size needed for this study was calculated by using the following equation (Pakpour et al., 2011):

$$
n=\frac{z^{2} p(1-p)}{d^{2}}
$$

where: $n=$ Sample size; $z=$ Standard normal distribution (1.96); $p$ = Estimated mean of incidence proportion observed for the depression in the city of Karachi (i.e. $0.05) ; d=$ Standard error (0.05).

$$
n=\frac{(1.96)^{2} \times(0.05) \times(1-0.05)}{(0.05)^{2}} \quad(\mathrm{n}=73)
$$

Instead of taking least sample size of 73 patients, a relatively large sample size was taken into consideration, i.e. taking one patient from each strata or union councils $(\mathrm{n}=178)$ patients each for fluoxetine and Hypericum perforatum based therapies. By taking an Average Annual Household Income Per Person (AAHIPP) at Rs. 99,150/- 
(Pakistan Statistical Pocket Book 2006, 2006), the 356 patients were selected as stratified random samples from population of 7,755,189 (approx. 7.76 million). The patients were segregated by their age and the process of data collection was completed in accordance with the proportions of each group out of 11 different age groups (i.e. Table I: from 25-75+ years with difference of 5 years in between) as defined by the Pakistan Bureau of Statistics (Pakistan Statistical Pocket Book, 2006). Following formula was used for the sample size based on age groups:

$$
\left(\begin{array}{c}
\text { Age Group Based } \\
\text { Sample Size }
\end{array}\right)=\frac{\left(\begin{array}{c}
\text { Percentage of Age } \\
\text { Group in Population }
\end{array}\right)}{100} \times \text { Sample Size }
$$

\section{Clarity of variables in the study}

Study Perspective: The societal perspective was followed for the present study for both the fluoxetine and Hypericum perforatum therapies for the depression. Time Horizon: The data of the 356 patients sampled for the Fluoxetine and Hypericum perforatum therapies were collected for one year (i.e. from March 2015 to February 2016). Description of decision-analytical model: A simple decision tree model was used as a guide within the specified time horizon. Uncertainty: 'Standard deviation' (SD) and 'Standard Error of Mean' (SEM) were used as the two main parameters of statistical uncertainty for the study (Table III).

TABLE I - Percentage-wise division of sample size of 178 patients among age groups in depression along with the analysis of age and gender homogeneity between the groups

\begin{tabular}{|c|c|c|c|c|c|c|c|c|c|}
\hline \multirow[b]{2}{*}{ S. No. } & \multirow[b]{2}{*}{$\begin{array}{c}\text { Age Groups } \\
\text { (In Years) }\end{array}$} & \multirow[b]{2}{*}{$\begin{array}{c}\text { \% of } \\
\text { Total } \\
\text { Populace }\end{array}$} & \multirow[b]{2}{*}{$\begin{array}{l}\text { Actual } \\
\text { Sample } \\
\text { Size Per } \\
\text { Therapy }\end{array}$} & \multicolumn{3}{|c|}{ Fluoxetine Based Therapy } & \multicolumn{3}{|c|}{ Hypericum perforatum Based Therapy } \\
\hline & & & & $\begin{array}{l}\text { Gender in } \\
\text { Age Groups }\end{array}$ & $\begin{array}{c}\text { Age } \\
\text { (Maximum } \\
\text { No. of } \\
\text { Patients) } \\
\end{array}$ & $\begin{array}{c}\text { Gender in } \\
\text { Maximum } \\
\text { No. of } \\
\text { Patients } \\
\end{array}$ & $\begin{array}{l}\text { Gender in } \\
\text { Age Groups }\end{array}$ & $\begin{array}{c}\text { Age } \\
\text { (Maximum } \\
\text { No. of } \\
\text { Patients) } \\
\end{array}$ & $\begin{array}{c}\text { Gender in } \\
\text { Maximum } \\
\text { No. of } \\
\text { Patients } \\
\end{array}$ \\
\hline 1 & $\begin{array}{c}25-29 \\
\text { years }\end{array}$ & 7.37 & 35 & $\begin{array}{c}\text { Male: } 23 \\
\text { Female: } 12\end{array}$ & $\begin{array}{c}28 \text { years } \\
\text { (10 patients) }\end{array}$ & $\begin{array}{c}\text { Male: } 8 \\
\text { Female: } 2\end{array}$ & $\begin{array}{c}\text { Male: } 15 \\
\text { Female: } 20\end{array}$ & $\begin{array}{c}25 \text { years } \\
\text { (10 patients) }\end{array}$ & $\begin{array}{c}\text { Male: } 5 \\
\text { Female: } 5\end{array}$ \\
\hline 2 & $\begin{array}{c}30-34 \\
\text { years }\end{array}$ & 6.22 & 30 & $\begin{array}{c}\text { Male: } 14 \\
\text { Female: } 16 \\
\end{array}$ & $\begin{array}{c}32 \text { years } \\
(9 \text { patients }) \\
\end{array}$ & $\begin{array}{c}\text { Male: } 4 \\
\text { Female: } 5 \\
\end{array}$ & $\begin{array}{c}\text { Male: } 14 \\
\text { Female: } 16 \\
\end{array}$ & $\begin{array}{c}31 \text { years } \\
\text { (8 patients) }\end{array}$ & $\begin{array}{c}\text { Male: } 5 \\
\text { Female: } 3 \\
\end{array}$ \\
\hline 3 & $\begin{array}{c}35-39 \\
\text { years }\end{array}$ & 4.77 & 23 & $\begin{array}{c}\text { Male: } 11 \\
\text { Female: } 12\end{array}$ & $\begin{array}{c}35 \text { years } \\
(7 \text { patients }) \\
\end{array}$ & $\begin{array}{c}\text { Male: } 4 \\
\text { Female: } 3 \\
\end{array}$ & $\begin{array}{c}\text { Male: } 10 \\
\text { Female: } 13 \\
\end{array}$ & $\begin{array}{c}35 \text { years } \\
\text { (8 patients) }\end{array}$ & $\begin{array}{l}\text { Male: } 5 \\
\text { Female: } 3\end{array}$ \\
\hline 4 & $\begin{array}{c}40-44 \\
\text { years }\end{array}$ & 4.45 & 21 & $\begin{array}{l}\text { Male: } 14 \\
\text { Female: } 7\end{array}$ & $\begin{array}{c}44 \text { years } \\
\text { (6 patients) }\end{array}$ & $\begin{array}{l}\text { Male: } 4 \\
\text { Female: } 2\end{array}$ & $\begin{array}{l}\text { Male: } 11 \\
\text { Female: } 10\end{array}$ & $\begin{array}{c}42,43,44 \\
\text { years } \\
\text { (15 patients) } \\
\end{array}$ & $\begin{array}{l}\text { Male: } 7 \\
\text { Female: } 8\end{array}$ \\
\hline 5 & $\begin{array}{c}45-49 \\
\text { years }\end{array}$ & 3.53 & 17 & $\begin{array}{l}\text { Male: } 11 \\
\text { Female: } 6\end{array}$ & $\begin{array}{c}48 \text { years } \\
(6 \text { patients }) \\
\end{array}$ & $\begin{array}{c}\text { Male: } 6 \\
\text { Female: } 0\end{array}$ & $\begin{array}{c}\text { Male: } 6 \\
\text { Female: } 11 \\
\end{array}$ & $\begin{array}{c}46 \text { years } \\
\text { (5 patients) }\end{array}$ & $\begin{array}{c}\text { Male: } 1 \\
\text { Female: } 4\end{array}$ \\
\hline 6 & $\begin{array}{c}50-54 \\
\text { years }\end{array}$ & 3.21 & 15 & $\begin{array}{l}\text { Male: } 11 \\
\text { Female: } 4\end{array}$ & $\begin{array}{l}50,51 \text { years } \\
\text { (10 patients) }\end{array}$ & $\begin{array}{c}\text { Male: } 7 \\
\text { Female: } 3 \\
\end{array}$ & $\begin{array}{c}\text { Male: } 8 \\
\text { Female: } 7 \\
\end{array}$ & $\begin{array}{c}50 \text { years } \\
(4 \text { patients }) \\
\end{array}$ & $\begin{array}{c}\text { Male: } 1 \\
\text { Female: } 3 \\
\end{array}$ \\
\hline 7 & $\begin{array}{c}55-59 \\
\text { years }\end{array}$ & 2.15 & 10 & $\begin{array}{c}\text { Male: } 4 \\
\text { Female: } 6\end{array}$ & $\begin{array}{c}58 \text { years } \\
(4 \text { patients }) \\
\end{array}$ & $\begin{array}{c}\text { Male: } 3 \\
\text { Female: } 1 \\
\end{array}$ & $\begin{array}{c}\text { Male: } 7 \\
\text { Female: } 3 \\
\end{array}$ & $\begin{array}{l}56,57 \text { years } \\
(4 \text { patients })\end{array}$ & $\begin{array}{c}\text { Male: } 2 \\
\text { Female: } 2\end{array}$ \\
\hline 8 & $\begin{array}{c}60-64 \\
\text { years }\end{array}$ & 2.04 & 10 & $\begin{array}{l}\text { Male: } 3 \\
\text { Female: } 7 \\
\end{array}$ & $\begin{array}{c}61 \text { years } \\
(4 \text { patients }) \\
\end{array}$ & $\begin{array}{c}\text { Male: } 0 \\
\text { Female: } 4 \\
\end{array}$ & $\begin{array}{c}\text { Male: } 5 \\
\text { Female: } 5\end{array}$ & $\begin{array}{c}64 \text { years } \\
\text { (5 patients) }\end{array}$ & $\begin{array}{c}\text { Male: } 4 \\
\text { Female: } 1 \\
\end{array}$ \\
\hline 9 & $\begin{array}{c}65-69 \\
\text { years }\end{array}$ & 1.20 & 6 & $\begin{array}{c}\text { Male: } 1 \\
\text { Female: } 5 \\
\end{array}$ & $\begin{array}{c}69 \text { years } \\
(3 \text { patients }) \\
\end{array}$ & $\begin{array}{c}\text { Male: } 1 \\
\text { Female: } 2\end{array}$ & $\begin{array}{c}\text { Male: } 4 \\
\text { Female: } 2\end{array}$ & $\begin{array}{c}68 \text { years } \\
(2 \text { patients }) \\
\end{array}$ & $\begin{array}{c}\text { Male: } 1 \\
\text { Female: } 1 \\
\end{array}$ \\
\hline 10 & $\begin{array}{c}70-74 \\
\text { years }\end{array}$ & 1.09 & 5 & $\begin{array}{c}\text { Male: } 3 \\
\text { Female: } 2\end{array}$ & $\begin{array}{c}71 \text { years } \\
(2 \text { patients }) \\
\end{array}$ & $\begin{array}{l}\text { Male: } 2 \\
\text { Female: } 0\end{array}$ & $\begin{array}{c}\text { Male: } 3 \\
\text { Female: } 2\end{array}$ & $\begin{array}{c}70 \text { years } \\
\text { (2 patients) } \\
\end{array}$ & $\begin{array}{c}\text { Male: } 1 \\
\text { Female: } 1 \\
\end{array}$ \\
\hline 11 & $\begin{array}{c}75 \text { years \& } \\
\text { up }\end{array}$ & $1.21 \%$ & 6 & $\begin{array}{l}\text { Male: } 4 \\
\text { Female: } 2\end{array}$ & $\begin{array}{c}75,87,88, \\
89,90,95 \\
\text { years } \\
\text { (6 patients) } \\
\end{array}$ & $\begin{array}{l}\text { Male: } 4 \\
\text { Female: } 2\end{array}$ & $\begin{array}{l}\text { Male: } 2 \\
\text { Female: } 4\end{array}$ & $\begin{array}{c}76 \text { years } \\
\text { (2 patients) }\end{array}$ & $\begin{array}{l}\text { Male: } 0 \\
\text { Female: } 2\end{array}$ \\
\hline & & & & Total & Male/Female & $99 / 79$ & Male/Female & $85 / 93$ & \\
\hline
\end{tabular}


TABLE II - Theoretical Vs actual savings with the influence of annual inflation accumulated over time

\begin{tabular}{lcc}
\hline Year & $\begin{array}{c}\text { Theoretical Savings } \\
\text { (Rs. in Billion) }\end{array}$ & $\begin{array}{c}\text { Actual Savings } \\
\text { (Rs. in Billion) }\end{array}$ \\
\hline $1^{\text {st }}$ Year & 46.82 & 46.82 \\
$2^{\text {nd }}$ Year & 46.82 & 39.46 \\
$3^{\text {rd }}$ Year & 46.82 & 33.26 \\
$4^{\text {th }}$ Year & 46.82 & 28.03 \\
$5^{\text {th }}$ Year & 46.82 & 23.62 \\
\hline Total & $\mathbf{2 3 4 . 1 0}$ & $\mathbf{1 7 1 . 1 9}$ \\
\hline
\end{tabular}

Rs.: Pakistani rupees

\section{Survey instrument and data collection}

For obtaining the maximum data input from 356 patients selected in the research study, a bilingual layered style interviews, questionnaires and opinion surveys (Groves et al., 2011; Dillman, Smyth, Christian, 2014) were devised, which consists of a blend of open and closed-ended questions. The interviews were rarely used in situations where respondents were unable to feedback to the questionnaires due to diversified reasons. The questionnaires and opinion surveys were available to the respondents in the form of choices between paperbased as well as an online (survey with Limesurvey ${ }^{\mathrm{TM}}$

TABLE III - Cost, disability-adjusted life years, burden of illness, incremental cost-effectiveness ratio and budget impact assessments of Fluoxetine and Hypericum perforatum based therapies for depression in 178 union councils of the city of Karachi

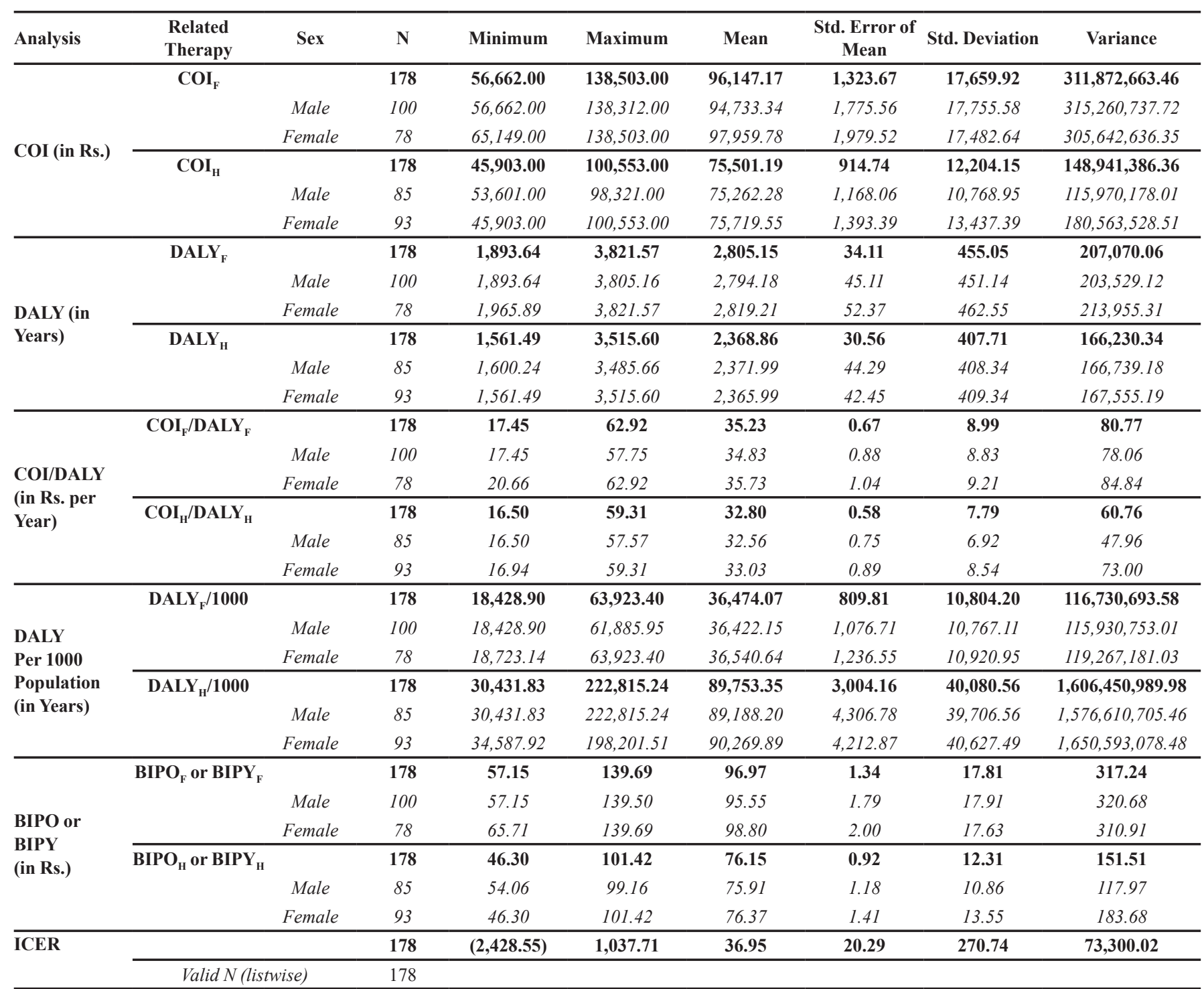

Rs.: Pakistani Rupees; COI: Cost of illness; DALY: Disability adjusted life years; COI/DALY: Cost per disability adjusted life year; BIPO: Budget impact per onset; BIPY: Budget impact per year; ICER: Incremental cost effectiveness ratio 
and surveymonkey.com). Surveys were the only mode of data collection that were more convenient to gather information. They were found relatively cheap and respondent-friendly than the interviews as surveys can be completed and submitted with patient's own ease and will.

\section{Utilization of database for data collection and preliminary calculations}

Since there were no database available for the herbal and allopathic therapies chosen in relevance with the scope of the study, therefore, the fresh data were collected from 356 patients from 178 union councils in the city of Karachi. The information gathered from either interviews, questionnaires or opinion surveys were distributed into two categories. The first category of data deal with epidemiological data including incidences as well as old cases to calculate the prevalence of depression. The second category of data deal with the addresses of patients including their towns and union councils, their genders and age, the monthly household income, fees of physicians/ herbal practitioners, the cost of medicines and transport, the loss of income and the loss due to pain experienced in the condition of depression. All the data input was used to calculate: the disability adjusted life years (DALY), an incremental cost effectiveness ratio (ICER), budget impact per onset (BIPO), budget impact per onset differences (BIPOD), budget impact per year (BIPY), budget impact per year differences (BIPYD) and the actual savings.

\section{Data analysis}

The data were gathered gradually and calculated into meaningful and required pharmacoeconomic evaluations (cost utility analysis and the budget impact analysis) via software, i.e. with Microsoft Excel 2016. The detailed statistical analysis was performed along with graph generation with the help of IBM ${ }^{\circledR}$ SPSS version 23 . For the Cost utility analysis and Budget impact analysis we divided the process in different stages for better understanding of collected data and ease of calculations.

Cost utility analysis was carried out in four steps as follows:

- To determine 'prevalence' of depression in 178 union councils of the city of Karachi.

- To calculate 'cost utility' (by utilizing results from calculations for 'prevalence' and the 'cost of illness' with exchange rate of Rs. 104/- per USD):

o The 'disability adjusted life years (DALYs)'.

o The 'disability adjusted life years (DALYs) per 1000 people'. o The 'cost of illness per disability adjusted life year' (COI per DALY).

o The 'incremental cost effectiveness ratios' by computing the results from calculations of 'cost of illness' and the 'disability adjusted life years (DALYs).

The budget impact analysis was carried out in five steps:

- $\quad$ First step was to utilize the results of 'cost of illness' and the 'average annual household income per person (AAHIPP)' in the calculation of 'budget impact per onset (BIPO)' for each patient receiving fluoxetine or Hypericum perforatum treatments.

- The second step was to determine the 'budget impact per onset difference (BIPOD)' between BIPOs.

- The third step was to utilize the results of 'cost of illness' and the 'average annual household income per person (AAHIPP)' in the calculation of 'budget impact per year (BIPY)' for each patient.

- $\quad$ The fourth step was to calculate the 'budget impact per year difference (BIPYD)' between BIPYs.

- The fifth step was to determine and compare the 'actual savings' with the 'theoretical savings' in context of the societal perspective.

The overall perspective of data analysis was to analyze 'what if' all the patients in the city of Karachi were treated with only one of the therapies to determine pharmacoeconomically best therapy for depression in the society. For the cost utility analysis and budget impact analysis we divided the process in different stages for better understanding of collected data and ease of calculations.

\section{Prevalence}

Prevalence was calculated by summing up new cases for reported depression and the old cases existed in Karachi (Sullivan et al., 2014). The data for the total population were calculated from the Pakistan Bureau of Statistics (Pakistan Statistical Pocket Book, 2006). While incidences and data of old cases were gathered from clinics and hospitals exist in all 178 union councils of Karachi. Prevalence was calculated by:

$$
\text { Prevalence }=[\text { Incidence }+ \text { Old Cases }]
$$

where, Incidence $=$ No. of new cases reported within time of study; Old Cases $=$ No. of old cases reported within time of study.

\section{Cost of Illness}

Cost of illness was calculated for its utilization 
for USD per DALY and in calculations for incremental cost effectiveness ratio (ICER). The cost of illness was calculated by summing up direct and indirect costs (Sullivan et al., 2014):

$$
\text { Cost of Illness }=[\text { Direct Costs }+ \text { Indirect Costs }]
$$

where, Direct Costs $=$ Fee of Practitioner + Costs of Medicine + Transport Costs; Indirect Costs $=$ Loss of Income + Loss due to Pain

\section{Disability Adjusted Life Years (DALYS)}

For each patient in either of the Fluoxetine and Hypericum perforatum treatments, the disability-adjusted life years (DALYs) were calculated, by summing up the years of lifetime lost (YLL) due to the premature death and the years that are misplaced (YLD) due to the disability. The discount rate of $3 \%$ was considered in the study utilizing the following formulas (Donev et al., 2010):

$$
\mathrm{DALY}=\mathrm{YLL}+\mathrm{YLD}
$$

where,

$$
\begin{gathered}
Y L L=\frac{N}{r}\left(1-e^{-r^{*} L_{D T}}\right) \\
Y L D=\frac{P^{*} D W\left(1-e^{-r^{*} L_{D B}}\right)}{r}
\end{gathered}
$$

therefore,

$$
D A L Y=\left[\left\{\frac{N}{r}\left(1-e^{-r^{*} L_{D T}}\right)\right\}+\left\{\frac{P^{*} D W\left(1-e^{-r^{*} L_{D B}}\right)}{r}\right\}\right]
$$

where, $N=$ number of deaths; $r=$ discount rate (constant rate of 0.03 in clinical calculations); $e=$ natural logarithm (constant value of approx. 2.71828); $L_{D T}=$ standard life expectancy at age of death in years; $P=$ prevalence of depression; $D W=$ disability weight i.e. 0.294 for depression (Haagsma et al., 2015); $L_{D B}=$ average duration of the case until remission or death (years).

The DALY per 1000 people was calculated by following formula:

$$
\text { DALY per } 1000 \text { People }=\frac{\text { Prevalence }}{1000} * \text { DALY of a Single Patient }
$$

The COI per DALY was calculated with the help of input cost of illness:

$$
\text { COI per DALY }=\frac{\text { COI in Rs. for a Single Patient }}{\text { DALY of a Single Patient }}
$$

\section{Incremental Cost Effectiveness Ratio (ICER)}

The incremental cost-effectiveness ratio (ICER) was calculated as part of cost-utility assessment, computing the costs and the disability adjusted life years (DALYs) of both Fluoxetine and the Hypericum perforatum therapies. A formula employed (Muennig, Bounthavong, 2016) to calculate the incremental cost-effectiveness ratio (ICER) was:

$$
I C E R=\left[\frac{\left(C O I_{F}-C O I_{H}\right)}{\left(D A L Y_{F}-D A L Y_{H}\right)}\right]
$$

In the year 2016, the gross domestic product (GDP) per capita income for Pakistan was Rs. 152,692.07/(World Bank, 2016) and with reference to it, the GDP per capita threshold (that was supposed to be 4 times less than the GDP per capita) was Rs. 38,173.02/-. In order to be identified as the preferred and economically beneficial therapy, the cost per disability-adjusted life year for either of the therapies elaborated in the treatment of depression must remain under the GDP per capita threshold (WHO, 2016).

\section{Budget impact per onset (BIPO)}

BIPOs, both for allopathic and herbal therapies of depression were calculated by the following formula:

For the allopathic therapy with Fluoxetine:

$$
B I P O_{F}=\frac{\left[A A H I P P-\left(A A H I P P-C O I_{F}\right)\right]}{A A H I P P}
$$

For the herbal therapy with Hypericum perforatum:

$$
B I P O_{H}=\frac{\left[A A H I P P-\left(A A H I P P-C O I_{H}\right)\right]}{A A H I P P}
$$

where, $\mathrm{BIPO}_{\mathrm{F}}=$ budget impact per onset for the Fluoxetine; $\mathrm{BIPO}_{\mathrm{H}}=$ budget impact per onset for the Hypericum perforatum; $\mathrm{COI}_{\mathrm{F}}=$ cost of illness with the fluoxetine; $\mathrm{COI}_{\mathrm{H}}=$ cost of illness with the Hypericum perforatum; AAHIPP $=$ average annual household income per person.

\section{Budget impact per onset difference (BIPOD)}

For budget impact per onset difference, again the fluoxetine therapy was given a benefit of doubt and therefore, the budget impact per onset in the Hypericum perforatum therapy $\left(\mathrm{BIPO}_{\mathbf{H}}\right)$ was subtracted from the 
budget impact per onset in Fluoxetine therapy $\left(\mathrm{BIPO}_{\mathrm{F}}\right)$. The budget impacts per onset difference (BIPOD) between $\mathrm{BIPO}$ of allopathic and herbal therapies of depression (i.e. $\mathrm{BIPO}_{\mathrm{F}}$ and $\mathrm{BIPO}_{\mathrm{H}}$ ) were calculated by following formula:

$$
\mathrm{BIPOD}=\mathrm{BIPO}_{\mathrm{F}}-\mathrm{BIPO}_{\mathrm{H}}
$$

or

$B I P O D=\left[\frac{\left\{A A H I P P-\left(A A H I P P-C O I_{F}\right)\right.}{A A H I P P}\right]-\left[\frac{\left\{A A H I P P-\left(A A H I P P-C O I_{H}\right)\right\}}{A A H I P P}\right]$

Budget impact per year (BIPY):

The budget impacts per year (BIPY) were calculated by the following formula:

For the allopathic therapy with Fluoxetine:

$$
B I P Y_{F}=\frac{\left[A A H I P P-\left\{A A H I P P-\left(C O I_{F}^{*} f\right)\right\}\right.}{A A H I P P}
$$

For the herbal therapy with Hypericum perforatum:

$$
B I P Y_{H}=\frac{\left[A A H I P P-\left\{A A H I P P-\left(C O I_{H}^{*} f\right)\right\}\right.}{A A H I P P}
$$

\section{Budget impact per year difference (BIPYD)}

Like the budget impact per onset difference, the budget impact per year in the Hypericum perforatum therapy $\left(\mathrm{BIPY}_{\mathrm{H}}\right)$ was subtracted from the budget impact per year in the Fluoxetine therapy $\left(\mathrm{BIPY}_{\mathrm{F}}\right)$. To calculate the budget impact per year difference (BIPYD) following formula was used:

$$
\mathrm{BIPYD}=\mathrm{BIPY}_{\mathrm{F}}-\mathrm{BIPY}_{\mathrm{H}}
$$

OR

$B I P Y D=\left[\frac{\left\{A A H I P P-\left(A A H I P P-\left(C_{F} * f\right)\right)\right\}}{A A H I P P}\right]-\left[\frac{\left\{A A H I P P-\left(A A H I P P-\left(C O I_{H} * f\right)\right)\right\}}{A A H I P P}\right]$

where, BIPY $_{\mathbf{F}}=$ budget impact per year for the Fluoxetine therapy; $\mathrm{BIPY}_{\mathbf{H}}=$ budget impact per year for the Hypericum perforatum therapy; $f=$ approx. yearly frequency of the depression.

\section{Projected actual savings}

Projected actual savings were calculated on basis of choice and the use of preferred treatment. To differentiate actual savings scenario from the theoretical/ideal saving scenario (where the inflation does not take part), the actual savings for current year with inflation were calculated by:
Projected actual savings for a year $=[$ Savinga of Last Year $\times\{1-(2 \times 0.0786)\}]$

\section{Extrapolation of the internal and external validity of the study findings}

Internal Validity: The univariate analysis of variance (One-way ANOVA) was performed, individually taking sex, age group, age, cost of illness, DALYs and BIPO as independent variables versus DALYs, DALYs/1000, BIPO, and ICER as dependent variable to find out the potential relationship among independent and dependent variables via identification of level of significance to validate internally the authenticity of the study findings.

External Validity: The same methodology was replicated for the dissimilar conditions such as common cold and trauma among a population in the city of Karachi, for retrospective cost-utility and budget impact assessments to carry out the external validity of the study findings.

\section{RESULTS}

The results for the cost utility and the budget impact analysis were:

\section{Prevalence of depression}

The prevalence of depression in selected population of Karachi was found to be at 2,268,127 (approx. 2.27 million) people (Table IV).

\section{Costs of Illness}

The annual cost of illness in Fluoxetine based allopathic therapy (Table IV) was estimated at Rs. 218.07/- billion (USD 2 billion and 96.83/- million) while for Hypericum perforatum based therapy at Rs. 171.25/- billion (USD 1 billion and 646.63/- million). There was a clear difference of Rs. $46.82 /$ - billion (USD $450.19 /$ - million) between the two therapies if projected over the patients of depression in the city of Karachi.

\section{Cost utility analysis}

Disability adjusted life years (DALYS)

The mean disability adjusted life years (DALYs) in cases of therapies with Fluoxetine and Hypericum perforatum were found to be 499,020.37 years and $353,150.95$ years respectively, with a difference of $145,869.42$ years (i.e. $29.23 \%$ ). 
TABLE IV - Cost, burden of illness and budget impact assessment of fluoxetine and Hypericum perforatum based therapies for the depression in the city of Karachi

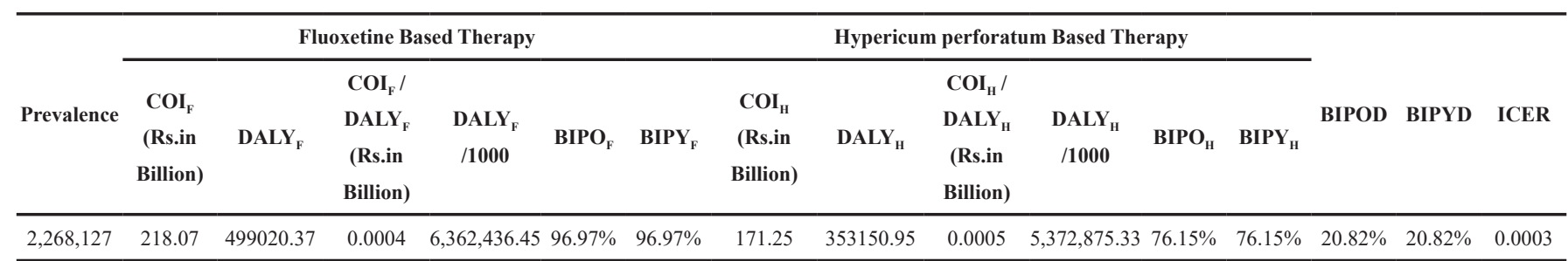

UC: Union Council; Pt.: Patient; Rs.: Pakistani Rupees; COI: Cost of illness; DALY: Disability adjusted life years; COI/DALY: Cost per disability adjusted life year; BIPO: Budget impact per onset; BIPY: Budget impact per year; BIPOD: Budget impact per onset difference; BIPYD: Budget impact per year difference; ICER: Incremental cost effectiveness ratio

\section{Disability adjusted life years (DALYs) per 1000 people}

The disability adjusted life years (DALYs) per 1000 people were 6,362,436.45 years and 5,372,875.33 years in case of treatment with fluoxetine and Hypericum perforatum respectively, with a difference of $989,561.13$ years. Considering the selected union councils population, disability adjusted life years (DALYs) per 1000 people were $36,474.07$ years and 89,753.35 years for fluoxetine and Hypericum perforatum, with a difference of 53279.28 years (Figure 2B).

\section{COI per DALY}

The COI per DALY was found to be at Rs. 35.23/and Rs. 32.80/- in Fluoxetine and Hypericum perforatum based therapies, with difference of Rs. 2.43/-.

\section{Incremental cost-effectiveness ratio (ICER)}

Mean ICER in Fluoxetine and Hypericum perforatum therapies (Table III) was observed to be at 36.95 per patient per onset of depression with SD of \pm 270.74 in the overall population. The ICER percentile $25^{\text {th }}$ and percentile $75^{\text {th }}$ were estimated at -0.03 and 82.28 respectively among 178 union councils of city of Karachi. The ICER with reference to the prevalence of depression was found to be at 0.0003 for city of Karachi (Table IV).

\section{Budget impact analysis}

\section{Budget impact per onset and budget impact per year}

Since, the depression is a multiple years long condition, the budget impact per onset (BIPO) and the budget impact per year (BIPY) based on average annual household income were both the same. It was estimated at $96.97 \%$ and $76.15 \%$ for fluoxetine and Hypericum perforatum therapies (Figure 3A). During the study, a direct relationship of COI was identified with BIPO and BIPY.
Budget impact per onset difference and budget impact per year difference

The budget impact per onset difference (BIPOD) and the budget impact per year difference (BIPYD) were both estimated at $20.82 \%$.

\section{Actual savings}

An annual savings of Rs.46.82/- billion (USD 450.19/- million) was calculated as a difference when using Hypericum perforatum as a mode of treatment (Figure 3B). However, the five-year savings of Rs.171.19/- billion (USD 1 billion and 646.06/- million) was found due to the dual impact of inflation rate in Pakistan (Table II)

\section{Analysis of age and gender homogeneity}

Although five (5) age groups, i.e. '25 - 29 yrs.', ' $40-44$ yrs.', ' $50-54$ yrs.', '55- 59 yrs.' and ' $70-74$ yrs.' (Table I; Figure 1) were found with more males than females; the four (4) age groups, i.e. ' $30-34$ yrs.', ' $35-39$ yrs.' ' ' $60-64$ yrs.', and ' $65-69$ yrs.' were found with more females than males. While only two (2) age groups, i.e. ' 45 - 49 yrs.' and ' 75 yrs. and up' were found with equal genders. Therefore, in overall 356 patients for both Fluoxetine and Hypericum perforatum based therapies, the number of males were found higher, i.e. 184 males than 172 females.

\section{Internal and external validation}

The univariate analysis of variance (One-way ANOVA) for the variables pointed out a very strong relationship between the cost of illness and the budget impact per onset by having significance level $<0.05$. No other potential relationship was identified among the variables, i.e. pointing towards the authenticity of the results of the study. The extrapolation of results of the study was expanded to two other retrospective studies on the same population of the city of Karachi for conditions of common cold and trauma revealing the preferences 


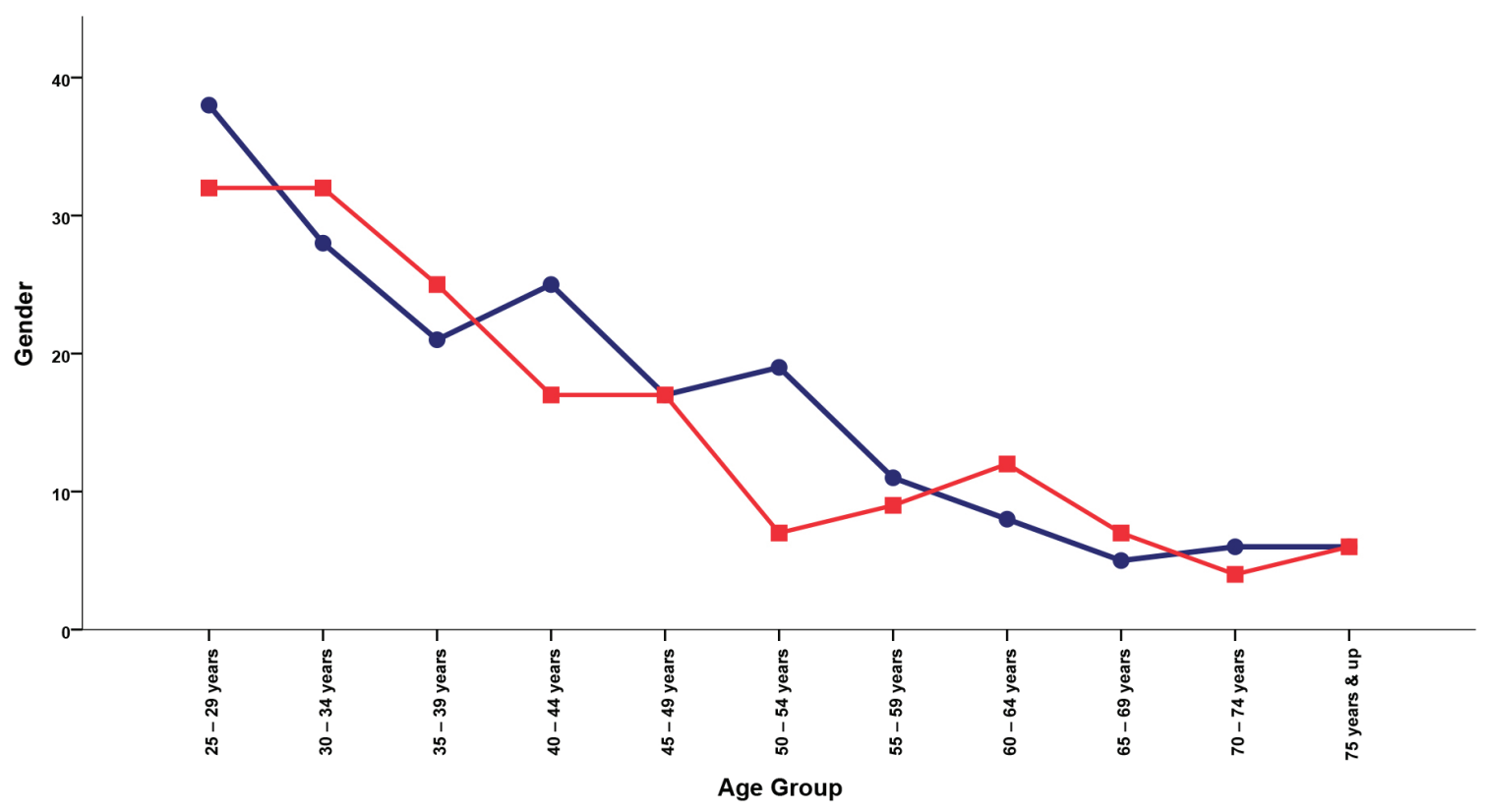

FIGURE 1 - Analysis of age and gender homogeneity in cost-utility and budget impact assessments of Hypericum perforatum in contrast with fluoxetine treatment (blue line with $\bullet$ marker: Male; red line with $\mathbf{m}$ marker: Female).

of herbal therapies over allopathic therapies in terms of providing more utility with less impact on the household budgets of patients.

\section{DISCUSSION}

It is well understood that in the cost utility analysis, the cost per disability-adjusted life years for either of the therapies calculated in terms of ICER (Muennig, Bounthavong, 2016) must remain under the GDP per capita threshold (WHO, 2016). As the study concluded that the ICER was 36.95 per patient per onset of depression with reference to the GDP per capita income for Pakistan (i.e. Rs. 152,692.07/- (World Bank, 2016), the ICER was found well below the GDP per capita threshold of Rs. 38,173.02/- (WHO, 2016).

Hypericum perforatum was found to have more utility than Fluoxetine because of lesser disability adjusted life years (i.e. having 145,869.42 years lesser; Figure 2A). Also, with reference to the comparative mean cost per DALY, it has the lower cost with a percentage difference of 6.90 , i.e. Rs. $2.43 /$-.

The budget impact analysis in the current study established the utility value of Hypericum perforatum as compare with the Fluoxetine based therapy. The budget impact per onset difference of $20.82 \%$ (or Rs. 46.82 billion, i.e. USD 450.19/- million) was found less impactful and could be hypothetically saved on a societal level, only if the patients with depression would get oral infusion of Hypericum perforatum as a medicine. This difference could be theoretically projected into five-years savings of Rs. 234.1/- billion (USD 2 billion and 250.96/- million). However, in practice, an annual savings (Figure 3B) of Rs.46.82/- billion (USD 450.19/million) would translate into five-year savings of Rs.171.19/- billion (USD 1 billion and 646.06/- million) due to the dual impact of inflation rate in Pakistan (Table II). This dual impact of inflation affects the supply of Hypericum perforatum against annual demand as well as on savings generated by Hypericum perforatum therapy. It must be noted that this value of accumulated savings is close to the cost incurred by the Hypericum perforatum therapy for the whole year in the city of Karachi. Therefore, the use of the Hypericum perforatum therapy is still beneficial in developing country like Pakistan where the poverty rate is very high due to the poor economic development and inequality in the society (Piazza, 2006; Fuentes-Nieva et al., 2014).

\section{CONCLUSION}

Considering the results of cost utility and the budget impact analysis along with the projected actual accumulative savings, the utilization of Hypericum perforatum based herbal therapy proved more pharmacoeconomically beneficial than the Fluoxetine based therapy for the treatment of depression in population of the city of Karachi. 
(A)
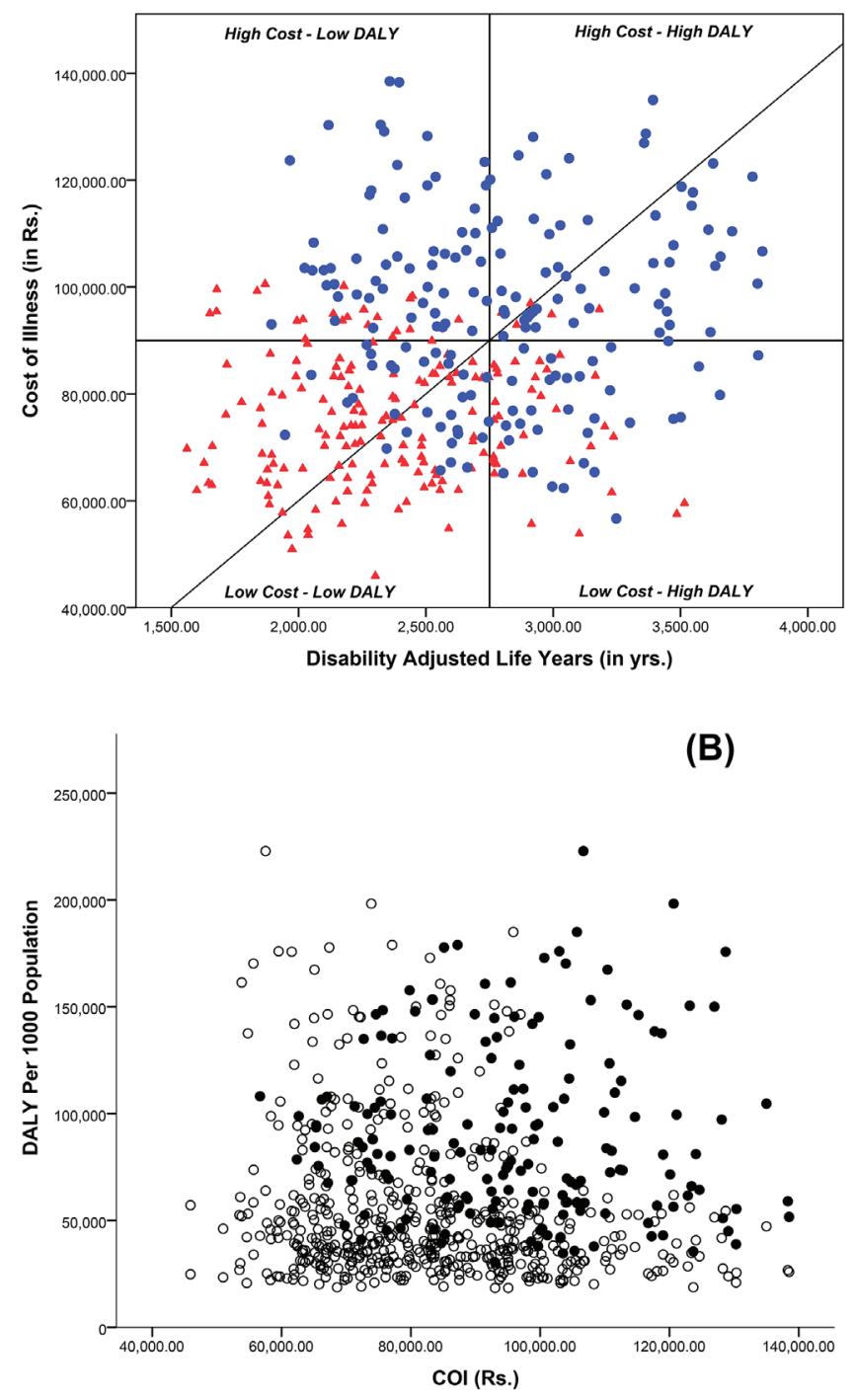

FIGURE 2 - Cost-utility assessment of Hypericum perforatum in contrast with fluoxetine treatment (A) COI Vs DALY fluoxetine and Hypericum perforatum in UCs (• blue marker - fluoxetine; $\mathbf{\Delta}$ red marker - Hypericum perforatum); (B) DALY 1000 Vs COI - fluoxetine and Hypericum perforatum in UCs (• fluoxetine; ○ Hypericum perforatum).

\section{ETHICAL CONSIDERATIONS}

Ethical issues (including plagiarism, informed consent, misconduct, data fabrication and/or falsification, double publication and/or submission, redundancy, etc.) have been completely observed by the authors.

\section{ACKNOWLEDGMENTS}

We are thankful to Mr. Aseer Ahmed Khan and Prof.
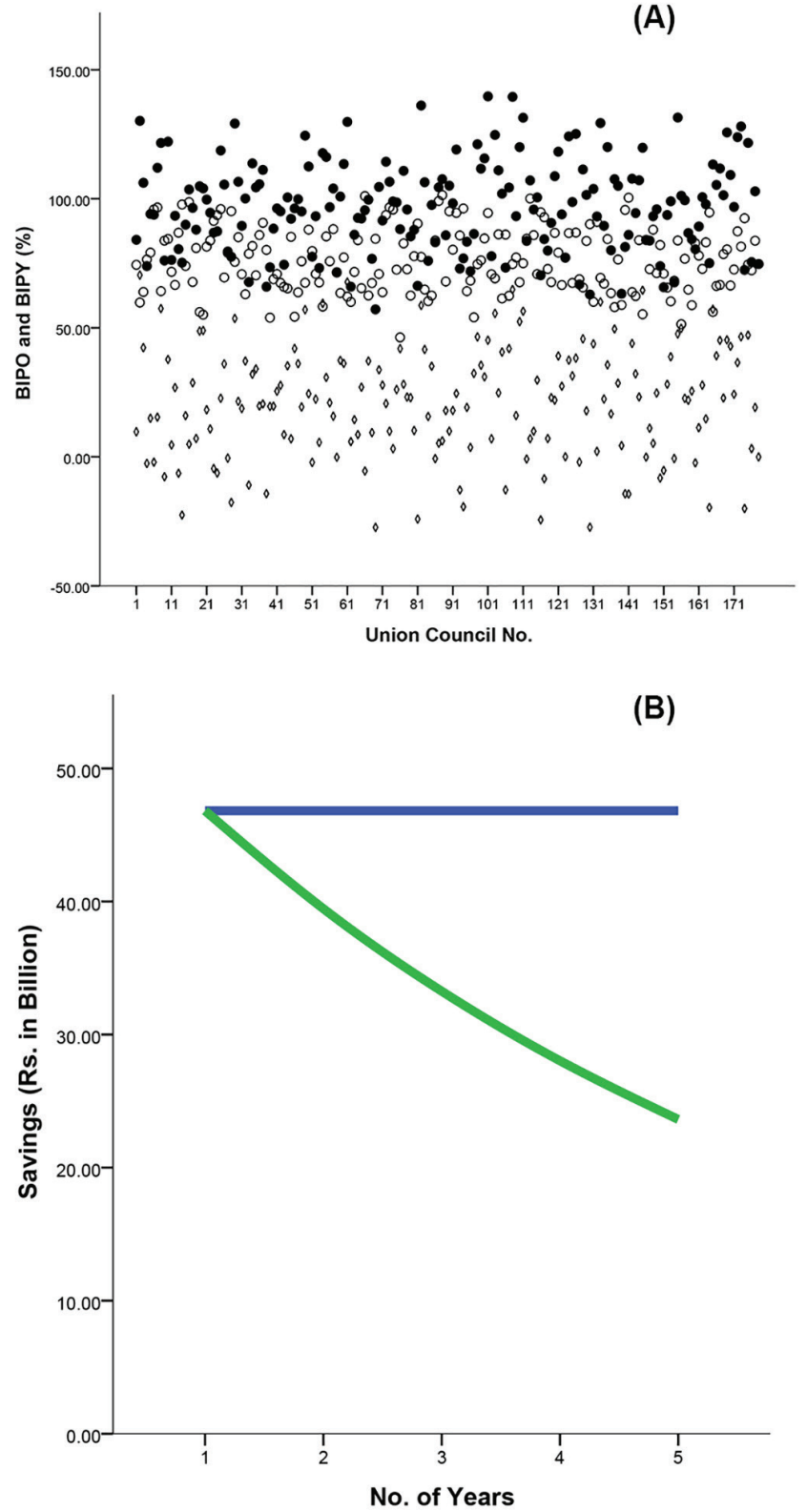

FIGURE 3 - Budget impact assessments of Hypericum perforatum in contrast with Fluoxetine treatment (A) Budget Impact Per Onset and Budget Impact Per Year in UCs $(\bullet$ BIPO and BIPY Fluoxetine; $\circ$ BIPO and BIPY Hypericum perforatum; $\checkmark$ BIPOD and BIPYD); (B) Theoretical Vs Actual Savings (Blue line: Theoretical Savings; Green line: Actual Savings).

Naeem Janjua (Late) for providing their deep insight and analytical support for the study.

\section{CONFLICT OF INTEREST}

The authors declare no conflict of interest regarding the publication of this paper. 


\section{REFERENCES}

Adkins D, Clark S, Åberg K, Hettema J, Bukszar J, McClay $\mathrm{J}$, et al. Genome-wide pharmacogenomic study of citalopraminduced side effects in STAR*D. Transl Psychiatry. 2012;2(7):e129.

Al-Qadhi W, Ur-Rahman S, Ferwana MS, Abdulmajeed IA. Adult depression screening in Saudi primary care: prevalence, instrument and cost. BMC Psychiatry. 2014;14(1):190.

Bukhari IA, Dar A. Behavioral profile of Hypericum perforatum (St. John's Wort) extract. A comparison with standard antidepressants in animal models of depression. Eur Rev Med Pharmacol Sci. 2013;17(8):1082-9.

Cheung G, Merry S, Sundram F. Do suicide characteristics differ by age in older people? Int Psychogeriatr. 2018;30(3):323-330.

Chrea B, O'Connell JA, Silkstone-Carter O, O’Brien J, Walsh JJ. Nature's antidepressant for mild to moderate depression: isolation and spectral characterization of hyperforin from a standardized extract of St. John's Wort (Hypericum perforatum). J Chem Educ. 2014;91(3):440-2.

Dillman DA, Smyth JD, Christian LM. Internet, phone, mail, and mixed-mode surveys: the tailored design method. John Wiley \& Sons; 2014.

Donev D, Zaletel-Kragelj L, Bjegovic V, Burazeri G. Measuring the burden of disease: disability adjusted life year (DALY). Meth Tools Pub Health. 2010;30:715.

Eddy DM, Hollingworth W, Caro JJ, Tsevat J, McDonald KM, Wong JB. Model transparency and validation: a report of the ISPOR-SMDM Modeling Good Research Practices Task Force-7. Med Decis Making. 2012;32(5):733-43.

Fuentes-Nieva R, Galasso N, Working for the Few: Political capture and economic inequality. Oxfam; 2014. 15 p.

Groves RM, Fowler Jr FJ, Couper MP, Lepkowski JM, Singer E, Tourangeau R. Survey methodology. John Wiley \& Sons; 2011.

Haagsma JA, De Noordhout CM, Polinder S, Vos T, Havelaar AH, Cassini A, Devleesschauwer B, Kretzschmar ME, Speybroeck N, Salomon JA. Assessing disability weights based on the responses of 30,660 people from four European countries. Popul Health Metr. 2015;13(1):10.
Huebner J, Prott FJ, Muecke R, Stoll C, Buentzel J, Muenstedt $\mathrm{K}$, et al. Economic Evaluation of Complementary and Alternative Medicine in Oncology: Is There a Difference Compared to Conventional Medicine? Med Princ Pract. 2017;26(1):41-9.

Husain GM, Chatterjee SS, Singh PN, Kumar VI. Beneficial effect of Hypericum perforatum on depression and anxiety in a type 2 diabetic rat model. Acta Pol Pharm. 2011;68(6):913-8.

Muennig P, Bounthavong M. Cost-effectiveness analysis in health: a practical approach. 3rd Ed. John Wiley \& Sons; 2016. p. 10 .

Oyekcin DG, Sahin EM, Aldemir E. Mental health, suicidality and hopelessness among University students in Turkey. Asian J Psychiatr. 2017;29:185-9.

Pakistan Inflation Rate. [cited 2017 Apr 04]. Available from: http://www.tradingeconomics.com/pakistan/inflation-cpi.

Pakistan Statistical Pocket Book 2006. [cited 2006 Dec 25]. Available from: http://www.pbs.gov.pk/content/pakistanstatistical-pocket-book-2006.

Pakpour AH, Hidarnia A, Hajizadeh E, Kumar S, Harrison AP. The status of dental caries and related factors in a sample of Iranian adolescents. Med Oral Patol Oral Cir Bucal. 2011;16(6):e822-7.

Piazza JA. Rooted in poverty?: Terrorism, poor economic development, and social cleavages. Terror Polit Violence. 2006;18(1):159-177.

Russo E, Scicchitano F, Whalley BJ, Mazzitello C, Ciriaco M, Esposito S, Patanè M, Upton R, Pugliese M, Chimirri S, Mammì M. Hypericum perforatum: pharmacokinetic, mechanism of action, tolerability, and clinical drug-drug interactions. Phytother Res. 2014;28(5):643-55.

Saki K, Bahmani M, Rafieian-Kopaei M. The effect of most important medicinal plants on two important psychiatric disorders (anxiety and depression)-a review. Asian Pac J Trop Med. 2014;7S1:S34-42.

Sarris J. St. John's wort for the treatment of psychiatric disorders. Psychiatr Clin North Am. 2013;36(1):65-72.

Solomon D, Adams J, Graves N. Economic evaluation of St. John's wort (Hypericum perforatum) for the treatment of mild to moderate depression. J Affect Disord. 2013;148(2-3):228-34. 
Sullivan SD, Mauskopf JA, Augustovski F, Caro JJ, Lee KM, Minchin M, Orlewska E, Penna P, Barrios JM, Shau WY. Budget impact analysis - principles of good practice: report of the ISPOR 2012 Budget Impact Analysis Good Practice II Task Force. Value Health. 2014;17(1):5-14.

Supartini A, Oishi T, Yagi N. Sex differences in the relationship between sleep behavior, fish consumption, and depressive symptoms in the general population of South Korea. Int J Environ Res Public Health. 2017;14(7):e789.

Tian J, Zhang F, Cheng J, Guo S, Liu P, Wang H. Antidepressantlike activity of adhyperforin, a novel constituent of Hypericum perforatum L. Sci Rep. 2014;4:5632.

Verhoeven JE, Révész D, Epel ES, Lin J, Wolkowitz OM, Penninx BW. Major depressive disorder and accelerated cellular aging: results from a large psychiatric cohort study. Mol Psychiatry. 2014;19(8):895-901.

Wong DT, Perry KW, Bymaster FP. The discovery of fluoxetine hydrochloride (Prozac). Nat Rev Drug Discov. 2005;4(9):76474.

World Bank Databank | World Development Indicator Pakistan. [cited 2016 Nov 15]. Available from: http://databank. worldbank.org/data/reports.aspx? source=2\&country=PAK\#.
World Health Organization. [cited 2016 Mar 29]. Policy and practice: Thresholds for the cost-effectiveness of interventions: alternative approaches. 2015. Available from: http://www.who. int/bulletin/volumes/93/2/14-138206/en/.

Wu GF, Ren S, Tang RY, Xu C, Zhou JQ, Lin SM, Feng Y, Yang QH, Hu JM, Yang JC. Antidepressant effect of taurine in chronic unpredictable mild stress-induced depressive rats. Sci Rep. 2017;7(1):4989.

Xu YY, Liang J, Cao Y, Shan F, Liu Y, Xia QR. High levels of Nesfatin-1 in relation to the dysfunction of the hypothalamicpituitary-adrenal and hypothalamus-pituitary-thyroid axes in depressed patients with subclinical hypothyroidism. Neuropsychiatr Dis Treat. 2017;13:1647-53.

Zhang L, Chen Y, Yue L, Liu Q, Montgomery W, Zhi L, Wang W. Medication use patterns, health care resource utilization, and economic burden for patients with major depressive disorder in Beijing, People's Republic of China. Neuropsychiatr Dis Treat. 2016;12:941-9.

Received for publication on $08^{\text {th }}$ April 2017 Accepted for publication on $22^{\text {nd }}$ August 2018 